\title{
Model Keterlibatan Pegawai dalam Entitas Non Profit di Era New Normal
}

\section{Anak Agung Ayu Kesuma Yuliantari', AA. Ngr. Eddy Supriyadinata Gorda ${ }^{2}$}

${ }^{1}$ Badan Rumah Sakit Umum Daerah (BRSUD) Kabupaten Tabanan, Tabanan, Indonesia

${ }^{2}$ Universitas Pendidikan Nasional (Undiknas) Denpasar, Denpasar, Indonesia

\section{A R T I C L E I N F O}

Article history:

Received August 13, 2021

Revised August 19, 2021

Accepted October 03 14, 2021

Available online October 25, 2021

Kata Kunci:

Keterlibatan Pegawai, Entitas Non Profit

Keywords:

Employee Involvement, Non-Profit Entities

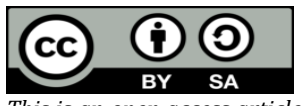

This is an open access article under the $\underline{C}$ BY-SA license.

Copyright (C) 2021 by Author. Published by Universitas Pendidikan Ganesha.

\begin{abstract}
A B S T R A K
Employee engagement merupakan wujud loyalitas karyawan terhadap perusahaan. Hanya saja kenyataan dilapangan menunjukkan bahwa tidak semua karyawan memiliki Employee engagement yang tinggi terhadap perusahaan. Adapun tujuan dari penelitian ini yakni untuk mengetahui dan menganalisis alasan kurang optimalnya keterlibatan pegawai dalam sebuah perusahaan. Penelitian ini tergolong kedalam jenis penelitian deskriptif kualitatif. Dengan subjek penelitian yakni penelitian yakni manajemen dan pegawai rumah sakit. Pengumpulan data dalam penelitian dilakukan dengan menggunakan metode observasi dan wawancara mendalam. Adapun instrument yang digunakan yakni pedoman wawancara dan observasi. Data hasil penelitian kemudian dianalisis dengan menggunakan Teknik analisis data kualitatif dengan model interaktif dari Miles dan Huberman. Verifikasi keabsahan hasil analisis dalam penelitian ini menggunakan cara triangulasi sumber data, artinya peneliti mengumpulkan data sejenis dari berbagai sumber data yang berbeda-beda. Hasil analisis penelitian menunjukkan bahwa belum optimalnya Employee engagement disebabkan oleh faktor budaya, indikator kesuksesan, penetapan prioritas, komunikasi, inovasi, akuisisi talenta, peningkatan talenta dan siklus pelanggan atau bisnis. Selain itu, disimpulkan juga bahwa identifikasi model upaya meningkatkan keterlibatan pegawai meliputi aspek lingkungan kerja, aspek kepemimpinan, aspek hubungan tim dan rekan kerja, aspek pelatihan dan pengembangan karir, aspek kompensasi, aspek kebijakan, prosedur, struktur dan sistem organisasi, serta aspek kesejahteraan di tempat kerja.
\end{abstract}

A BS TRACT

Employee engagement is a form of employee loyalty to the company. However, the reality on the ground shows that not all employees have high employee engagement with the company. The purpose of this study is to find out and analyze the reasons for the less than optimal involvement of employees in a company. This research belongs to the type of qualitative descriptive research. The research subject is research, namely hospital management and employees. Data collection in the study was carried out using the method of observation and in-depth interviews. The instruments used are interview and observation guidelines. The research data were then analyzed using qualitative data analysis techniques with an interactive model from Miles and Huberman. Verification of the validity of the analysis results in this study using triangulation of data sources, meaning that researchers collect similar data from various different data sources. The results of the research analysis show that employee engagement is not optimal due to cultural factors, success indicators, priority setting, communication, innovation, talent acquisition, talent improvement and customer or business cycles. In addition, it is also concluded that the identification of an effort to increase employee involvement includes aspects of the work environment, leadership aspects, aspects of team and co-worker relations, aspects of training and career development, aspects of compensation, aspects of policies, procedures, organizational structures and systems, as well as aspects of welfare at work. workplace.

\section{PENDAHULUAN}

Rumah sakit sebagai entitas non profit merupakan suatu organisasi di bidang kesehatan yang memiliki banyak sumber daya manusia dalam memberikan pelayanan kesehatan kepada masyarakat (Prananingrum, 2019). Sumber daya manusia yang terlibat dalam kegiatan operasional rumah sakit sangat beragam, mulai dari tenaga dokter, tenaga perawat dan tenaga kerja non-medis lainnya dan tidak terpisahkan satu sama lain dalam memberikan pelayanan kesehatan kepada masyarakat atau dengan kata lain harus saling bekerja sama (Subekti et al., 2018; Wahyudi, 2018). Setiap rumah sakit akan berusaha memberikan perhatian kepada pegawainya agar pegawai merasa memiliki keterlibatan dengan organisasi dan memberikan kinerja terbaiknya (Riansah \& Sri, 2019). Faktor dari dalam individu yang meliputi kepribadian, semangat kerja, dan motivasi ini ditemukan dalam teori baru di dunia akademik dan organisasi (Afiani et al., 2019; Lisabella \& Hasmawaty, 2021; Nafiudin, 2020; Rahmawati, 2022). Teori ini disebut teori 
employee engagement (keterlibatan pegawai). Employee engagement (keterlibatan pegawai) merupakan teori yang relatif baru di bidang manajemen, khususnya dalam sumber daya manusia (Chaerunissa \& Pancasasti, 2021; Deny \& Aslam, 2021). Employee engagement dijadikan sebagai alat manajerial yang diaksanakan secara terus menerus untuk mendapatkan momentum dalam praktek manajemen modern (Pusriadi \& Darma, 2020; Sabbatho et al., 2021). Selain dapat memberikan kontribusi yang lebih untuk organisasi, pegawai yang engaged relatif lebih loyal dan karenanya lebih kecil kemungkinannya untuk meninggalkan oganisasi yang mereka tempati (Fitriani, 2019).

Keterlibatan pegawai (employee engagement) dalam sebuah organisasi terbagi menjadi 2 (dua) yaitu pegawai yang employee engagement-nya tinggi dan pegawai yang employee engagement-nya rendah (Prahara \& Putri, 2020; Tabun, 2021). Pegawai yang employee engagement-nya tinggi ditandai dengan tingginya level energi dan resiliensi mental saat bekerja, kemauan untuk memberi upaya dalam bekerja dan ketekunan dalam menghadapi kesulitan, memiliki ikatan diri secara emosional dan intelektual pada pekerjaan, serta berkonsentrasi penuh dan memiliki kesenangan dalam bekerja, selain itu seseorang yang memiliki employee engagement tinggi akan merasa waktu berjalan begitu cepat sehingga sulit untuk melepas diri dari pekerjaannya (Steven \& Prihatsanti, 2017). Sedangkan pegawai yang employee engagement-nya rendah akan memiliki level energi dan resiliensi mental yang rendah saat bekerja, memiliki kemauan yang rendah untuk memberi upaya dalam bekerja dan ketekunan dalam menghadapi kesulitan, kurang menunjukkan adanya ikatan diri secara emosional dan intelektual pada pekerjaan, serta tidak berkonsentrasi penuh dan kurang senang bekerja (Prahara \& Putri, 2020; Tabun, 2021). Sehingga dalam bekerja, dimana waktu berjalan lambat dan individu mudah melepas diri dari pekerjaannya.

Fenomena dilapangan menunjukkan bahwa tidak semua pegawai mempunya employee engagement yang tinggi (Nurdini \& Firmansyah, 2022). Hal ini sejalan dengan hasil observasi di Badan Rumah Sakit Umum Daerah (BRSUD) Kabupaten Tabanan. Hasil observasi menunjukkan bahwa motivasi kerja pegawai bila diukur dari 0 sampai dengan $100 \%$, maka motivasi ini dinilai $70 \%$; produktivitas pegawai dinilai 70\%; disiplin kerja, kepatuhan, ketaatan dan pemahaman akan aturan kerja dinilai 65\%; aktif menanggapi permasalahan organisasi dinilai 40\%; serta melakukan pekerjaan di atas job desc-nya dinilai 25\%. Pegawai melakukan pekerjaan di atas job desc-nya mengandung makna bahwa pegawai tersebut bersedia melakukan pekerjaan tambahan di luar tugas dari tanggungjawabnya namun masih di departemen atau bagian yang sama. Contohnya seorang perawat rumah sakit yang mau mengamankan keluarga pasien kalau ada keributan yg di buat oleh keluarga pasien meskipun perawat tersebut tahu bahwa itu bukan tugas dan tanggungjawabnya, tetapi tugas dan tanggungjawab satpam atau security. Contoh lainnya seorang pegawai keuangan yang tugasnya bertanggung jawab terhadap pembayaran tagihan kerekanan, ikut mencetak id billing bukti setor pajak yang bukan menjadi tugas dan tanggungjawabnya.

Kondisi tersebut menunjukkan bahwa employee engagement di BRSUD Kabupaten Tabanan memang belum optimal. Belum optimalnya employee engagement (keterlibatan pegawai) di BRSUD Kabupaten Tabanan ini semakin meningkat pada masa New Normal sebagai dampak dari Pandemi Covid19. Kondisi ini disebabkan pada masa New Normal, para pegawai di BRSUD Kabupaten Tabanan terkendala oleh adanya protokol kesehatan seperti jaga jarak, social distancing dan pembatasan jumlah pegawai yang bekerja hingga kebijakan work from home (WFH). Tinggi rendahnya Employee engagement dalam sebuah perusahaan secara tidak langsung akan memberikan dampak pada pada organisasi atau perusahaan, seperti kepuasan kerja, komitmen terhadap organisasi, dan menurunnya intensi turnover (Priambodo et al., 2019). Hal ini di karenakan employee engagement terkait dengan hasil kerja pegawai, kesuksesan perusahaan, dan financial performance (Nurcahyo, 2021). Hal ini disebabkan karena employee engagement dapat mendorong pegawai melakukan pekerjaan di atas job desc-nya (Priambodo et al., 2019). Sehingga ketika tingkat employee engagement dalam perusahaan tinggi maka akan memberikan dampak yang positif.

Beberapa penelitian yang telah dilakukan sebelumnya mengungkapkan bahwa employee engagement berpengaruh positif dan signifikan terhadap kinerja dan kepuasan kerja karyawan (Chaerunissa \& Pancasasti, 2021). Hasil penelitian lainnya juga mengungkapkan bahwa tanggapan pegawai atas talent management (managerial support, employee career development, dan rewards \& recognitions) dan employee engagement adalah tinggi, dan employee retention sangat tinggi, hal ini berarti bahwa praktek manajemen talenta yang efektif di organisasi dapat berdampak pada retensi pegawai melalui keterikatan pegawai, namun juga dapat berdampak langsung pada retensi pegawai (Srimulyani, 2020). Hasil penelitian selanjutnya mengungkapkan bahwa kuat-lemahnya budaya organisasi dan tingkat kepuasan kerja secara simultan memiliki pengaruh positif terhadap tingkat keterikatan karyawan (employee engagement) (Sopyan, 2018). Berdasarkan hasil penelitian tersebut dapat dikatakan bahwa tanggapan pegawai dalam employee engagement berada dalam kategori yang berbeda-beda, dimana employee engagement memberikan pengaruh terhadap kinerja karyawan serta berpengaruh terhadap kualitas layanan suatu perusahaan. Hanya saja pada penelitian sebelumnya belum terdapat kajian mengenai model keterlibatan 
pegawai dalam entitas non profit di era new normal, sehingga penelitian ini difokuskan pada kajian tersebut dengan tujuan untuk mengetahui dan menganalisis alasan keterlibatan pegawai BRSUD Kabupaten Tabanan yang belum optimal.

\section{METODE}

Penelitian ini merupakan penelitian deskriptif kualitatif, yang dilakukan untuk mengetahui suatu fenomena yang terjadi di masyarakat. Penelitian ini dilaksanakan di BRSUD Kabupaaten Tabanan dengan subjek penelitian yakni manajemen dan pegawai BRSUD. Pengumpulan data dalam penelitian dilakukan dengan menggunakan metode observasi dan wawancara mendalam. Adapun instrument yang digunakan yakni pedoman wawancara dan observasi. Data hasil penelitian kemudian dianalisis dengan menggunakan Teknik analisis data kualitatif dengan model interaktif dari Miles dan Huberman. Verifikasi keabsahan hasil analisis dalam penelitian ini menggunakan cara triangulasi sumber data, artinya peneliti mengumpulkan data sejenis dari berbagai sumber data yang berbeda-beda.

\section{HASIL DAN PEMBAHASAN}

\section{Hasil}

Hasil analisis penelitian menunjukkan bahwa terdapat dua temuan dalam penelitian ini. Temuan pertama berkaitan dengan factor-faktor yang mempengaruhi belum optimalnya keterlibatan pegawai BRSUD Kabupaten Tabanan. Adapun faktor tersebut terdiri dari faktor budaya, indikator kesuksesan, penetapan prioritas, komunikasi, inovasi, akuisisi talenta, peningkatan talenta dan siklus pelanggan atau bisnis. Pada faktor budaya organisasi, BRSUD Kabupaten Tabanan sangat dipengaruhi oleh budaya yang dianut masyarakat Bali. Salah satu budaya yang dijunjung tinggi yakni budaya yang bersifat komunal dan gotong royong justru menjadikan budaya organisasi menjadi budaya yang kurang kompetitif. Hal itu menjadikan employee engagement sulit diwujudkan di BRSUD Kabupaten Tabanan. Selanjutnya pada faktor Indikator Kesuksesan, dapat dilihat dari ukuran kesuksesan pegawai BRSUD Kabupaten Tabanan yakni apabila pegawai yang bersangkutan telah mengerjakan job description atau job desc-nya atau belum. Untuk menilai apakah jobdesc. tersebut telah dilaksanakan dengan baik, masing-masing pegawai diberikan Key Performance Indicator (KPI). Fungsi KPI seperti raport pada anak sekolah. Namun belum semua pegawai dapat mencapai hal-hal yang telah digariskan dalam KPI-nya.

Pada faktor penetapan prioritas, pegawai yang bisa bekerja dengan baik adalah pegawai yang bisa menetapkan prioritas. Artinya pekerjaan yang penting-penting didahulukan, sedang yang kurang penting dijadwalkan pengerjaannya, bukan ditinggalkan. Membuat prioritas bukan berarti meninggalkan pekerjaan yang kurang penting, tetapi pekerjaan yang penting diprioritaskan pengerjaannya lebih dahulu. Jika semua pekerjaan dianggap penting, pegawai akan kesulitan menyusun prioritas sehingga hasil pekerjaan kurang memuaskan. Selanjutnya pada faktor komunikasi, ditemukan bahwa pegawai BRSUD Tabanan belum dapat membangun komunikasi yang baik satu sama lain. Sebagai contoh pada proses pelaporan stock dibutuhkan rangkaian komunikasi antara pegawai gudang, pegawai pembelian dan pegawai keuangan. Begitu juga dengan laporan keuangan merupakan rangkaian komunikasi antara pegawai BRSUD Bagian Keuangan dengan seluruh stakeholder internal BRSUD Kabupaten Tabanan maupun dengan stakeholder eksternal di luar BRSUD Kabupaten Tabanan yang membutuhkan laporan keuangan itu.

Pada faktor inovasi, pegawai di BRSUD Kabupaten Tabanan dituntut harus bisa berinovasi dalam melaksankan pekerjaannya. Hanya saja banyak pegawai yang tidak mau berinovasi karena inovasi membutuhkan kreativitas dan keberanian, sedangkan banyak pegawai yang memilih bekerja secara amanaman saja. Pada umumnya pegawai-pegawai yang memiliki inovasi merasakan belum mendapatkan penghargaan memadai. Jadi seolah-olah bekerja dengan kreativitas dan inovasi tinggi penilaiannya sama saja. Hal inilah yang menyebabkan akhirnya pegawai memilih bekerja biasa-biasa saja, kalau hasil penilaiannya seperti sama saja. Selanjutnya pada faktor akuisi talenta, ditemukan bahwa akuisisi talenta belum sepenuhnya dijalankan di BRSUD Kabupaten Tabanan. Pada umumnya para pegawai berpendapat untuk dapat bekerja di BRSUD Kabupaten Tabanan memerlukan koneksi dan rekomendasi terutama dari pejabat-pejabat setempat. Selanjutnya dalam penilaian kinerja pun tidak mencerminkan adanya akuisisi talenta. Pegawai-pegawai yang dekat dengan atasan, yang dekat dengan pimpinan, yang bisa ABS (Asal Bapak Senang) akan dinilai baik dan akan dipermudah kenaikan pangkatnya. Sebaliknya pegawai yang tidak bisa ABS meskipun berprestasi, kreatif dan berinovasi, tetap saja mendapat penilain yang biasa-biasa saja.

Pada faktor selanjutnya yakni faktor peningkatan talenta, para pegawai di BRSUD Kabupaten Tabanan berpendapat bekerja di BRSUD Kabupaten Tabanan tidak harus meningkatkan talentanya. Mengingat bekerja dengan biasa-biasa saja di sini, kesempatan naik pangkat dan kenaikan gaji sama saja 
dengan pegawai berprestasi. Di sisi lain ada pegawai yang tidak berprestasi, namun karena faktor " $\mathrm{X}$ ", kenaikan pangkatnya cepat luar biasa, dan gajinyapun ikut meroket. Sehingga anggapan tidak perlu mengembangkan talenta di BRSUD Kabupaten Tabanan semakin berkembang. Selanjutnya pada faktor siklus pelanggan atau bisnis, hasil penelitian menunjukkan bahwa untuk mendapat pasien BRSUD Kabupaten Tabanan tidak perlu bersaing dengan rumah sakit lainnya. Jadi tanpa bersaingpun BRSUD Kabupaten Tabanan akan didatangi masyarakat menengah ke bawah yang membutuhkan pelayanan kesehatan dengan biaya terjangkau. Sedangkan masyarakat menengah atas tentunya akan lebih memilih rumah sakit swasta dengan kualitas pelayanan lebih tinggi.

Hasil penelitian kedua berkaitan dengan identifikasi model upaya meningkatkan keterlibatan pegawai BRSUD Kabupaten Tabanan. Adapun upaya yang dilakukan untuk meningkatkan employee engagement pegawai yakni dengan memperhatikan aspek lingkungan kerja, aspek kepemimpinan, aspek hubungan tim dan rekan kerja, aspek pelatihan dan pengembangan karir, aspek kompensasi, aspek kebijakan, prosedur, struktur dan sistem organisasi, serta aspek kesejahteraan di tempat kerja.

\section{Pembahasan}

Hasil analisis data menunjukkan bahwa employee engagement di BRSUD Tabanan masih berada dalam kategori rendah. Rendahnya employee engagement disebabkan oleh beberapa faktor diantaranya adalah faktor budaya, indikator kesuksesan, penetapan prioritas, komunikasi, inovasi, akuisisi talenta, peningkatan talenta dan siklus pelanggan atau bisnis. Employee engagement pada dasarnya merupakan komitmen emosional karyawan pada organisasi dan tujuannya (Nurfajar et al., 2018; Sucahyowati \& Hendrawan, 2020; Yusuf et al., 2019). Komitmen emosional merujuk pada kepedulian karyawan terhadap pekerjaan dan perusahaannya (Lansart et al., 2019; Pangestuti, 2018). Mereka tidak bekerja hanya untuk gaji, atau hanya untuk promosi, tetapi bekerja atas nama tujuan organisasi. Karyawan yang engaged tinggi merupakan karyawan yang telah memiliki hubungan erat dengan pekerjaannya sehingga akan bekerja keras untuk menyelesaikan pekerjaan sebaik dan secepat mungkin dengan usaha yang dimilikinya sehingga dapat mencapai tujuan perusahaan yang berhubungan dengan pekerjaannya (Ariawaty, 2019; Erwina, 2020; Manalu et al., 2021). Employee engagement dapat dibagi menjadi dua, yakni employee engagement tinggi dan employee engagement rendah. Tinggi rendahnya employee engagement yang dimiliki oleh karyawan tentunya akan memberikan dampak pada peningkatan kualitas perusahaan (Chairiza et al., 2018). Perusahaan akan dapat maju dan berkembang dengan baik apabila memiliki karyawan dengan employee engagement tinggi, begitu pula berlaku sebaliknya (Prativi \& Yulianti, 2020; Trisnawati et al., 2021). Peningkatan employee engagement karyawan dapat dilakukan dengan beberapa cara diantaranya adalah menigkatkan kualitas aspek lingkungan kerja, aspek kepemimpinan, aspek hubungan tim dan rekan kerja, aspek pelatihan dan pengembangan karir, aspek kompensasi, aspek kebijakan, prosedur, struktur dan sistem organisasi, serta aspek kesejahteraan di tempat kerja (Lina, 2019).

Aspek lingkungan kerja dikatakan dapat meningkatkan keterlibatan pegawai atau employee engagement, karena lingkungan kerja yang kompetitif bisa memberikan feed back atau umpan balik yang positif untuk mengembangkan keterampilan baru serta untuk memecahkan masalah yang berkaitan dengan pekerjaan (Rizki et al., 2021). Sehingga lingkungan kerja yang kompetitif tersebut secara tidak langsung akan mendorong terciptanya employee engagement (Ardiansyah \& Artadita, 2021). Selain aspek lingkungan kerja kepemimpinan juga menjadi aspek penting dalam peningkatan employee engagement karyawan, hal ini dikarenakan kepemimpinan diidentifikasi sebagai aspek dasar menumbuhkan employee engagement (Suryaningrum \& Silvianita, 2018). Kepemimpinan yang baik adalah kepemimpinan yang bisa menyelaraskan, memberdayakan, membina dan peduli pada pegawai-pegawai yang dipimpinnya (Abrianto \& Srimulyani, 2021). Gaya kepemimpinan transformasional yang cocok untuk menumbuhkan employee engagement karena gaya kepemimpinan transformasional mendukung saling pengertian antara pegawai dan juga berfokus pada pengembangan dari bawahan dan kebutuhan mereka, sementara pada level manajer gaya kepemimpinan transformasional berfokus pada pengembangan sistem nilai pegawai dan memberikan motivasi bagi bawahan (Angelia \& Astiti, 2020; Khasanah, 2019; Sirait, 2020).

Selanjutnya Aspek Hubungan Tim dan Rekan Kerja, juga dapat meningkatkan employee engagement (Lisabella \& Hasmawaty, 2021). Hubungan baik, dukungan dari rekan kerja dapat memotivasi pegawai untuk lebih terikat dengan perusahaan atau dengan perkataan lain dapat meningkatkan employee engagement (Suryaningrum \& Silvianita, 2018). Tim dan rekan kerja yang mampu diajak kerja sama dan mendukung dalam pelaksanaan kerja cenderung berpengaruh terhadap meningkatnya semangat kerja dan kinerja pegawai yang pada akhirnya dapat meningkatkan employee engagement (Layantara \& Perdhana, 2021). Hubungan kerja ini dicerminkan dari hubungan dengan tim dan rekan kerja, kerja sama antar rekan dalam satu unit kerja, kerja sama lintas unit kerja, dan kerja sama dengan departemen lain dalam organisasi secara keseluruhan. Aspek lainnya yang mampu meningkatkan employee engagement pegawai yakni Aspek Pelatihan dan Pengembangan Karir (Lina, 2019). Pelatihan dan pengembangan karir yang diberikan kepada 
pegawai memicu pegawai untuk dapat memahami sasaran yang harus dicapai (Chaerunissa \& Pancasasti, 2021). Selain itu, hal tersebut juga memicu pegawai untuk meningkatkan kinerja. Selain itu, pelatihan pengembangan karir yang diberikan kepada pegawai juga dapat mempengaruhi employee engagement (Kriswanta et al., 2021). Kepercayaan diri pegawai juga meningkat karena mereka sama-sama memiliki pemahaman dan pengetahuan yang sama terkait kondisi di lapangan dalam pelayanan kepada pasien.

Beberapa penelitian yang telah dilakukan sebelumnya mengungkapkan bahwa employee engagement berpengaruh positif dan signifikan terhadap kinerja dan kepuasan kerja karyawan (Chaerunissa \& Pancasasti, 2021). Hasil penelitian lainnya juga mengungkapkan bahwa tanggapan pegawai atas talent management (managerial support, employee career development, dan rewards \& recognitions) dan employee engagement adalah tinggi, dan employee retention sangat tinggi, hal ini berarti bahwa praktek manajemen talenta yang efektif di organisasi dapat berdampak pada retensi pegawai melalui keterikatan pegawai, namun juga dapat berdampak langsung pada retensi pegawai (Srimulyani, 2020). Hasil penelitian selanjutnya mengungkapkan bahwa kuat-lemahnya budaya organisasi dan tingkat kepuasan kerja secara simultan memiliki pengaruh positif terhadap tingkat keterikatan karyawan (employee engagement) (Sopyan, 2018). Berdasarkan hasil penelitian tersebut dapat dikatakan bahwa tanggapan pegawai dalam employee engagement berada dalam kategori yang berbeda-beda, dimana employee engagement memberikan pengaruh terhadap kinerja karyawan serta berpengaruh terhadap kualitas layanan suatu perusahaan. Adapun faktor-faktor yang mempengaruhi tinggi rendahnya employee engagement karyawan yakni faktor budaya, indikator kesuksesan, penetapan prioritas, komunikasi, inovasi, akuisisi talenta, peningkatan talenta dan siklus pelanggan atau bisnis.

\section{SIMPULAN}

Berdasarkan temuan penelitian dan pembahasan yang telah dikemukakan di atas, maka dapat disimpulkan alasan keterlibatan pegawai BRSUD Kabupaten Tabanan belum optimal disebabkan oleh faktor budaya, indikator kesuksesan, penetapan prioritas, komunikasi, inovasi, akuisisi talenta, peningkatan talenta dan siklus pelanggan atau bisnis. Selain itu, disimpulkan juga identifikasi model upaya meningkatkan keterlibatan pegawai BRSUD Kabupaten Tabanan meliputi aspek lingkungan kerja, aspek kepemimpinan, aspek hubungan tim dan rekan kerja, aspek pelatihan dan pengembangan karir, aspek kompensasi, aspek kebijakan, prosedur, struktur dan sistem organisasi, serta aspek kesejahteraan di tempat kerja.

\section{DAFTAR PUSTAKA}

Abrianto, H., \& Srimulyani, V. A. (2021). Peningkatan Employee Engagement melalui Budaya Organisasi dan Kepemimpinan Kredibel. Jurnal Riset Manajemen Dan Akuntansi, 09(July), 38-48. https://www.researchgate.net/profile/Jrma-Jrmaepemimpinan_Kredibeli.

Afiani, R., Surachim, A., \& Masharyono, M. (2019). Peran kepemimpinan transformasional dalam meningkatkan employee engagement dan dampaknya pada kinerja pegawai. Journal of Business Management Education (JBME), 4(1), 1-12. https://doi.org/10.17509/jbme.v4i1.15880.

Angelia, D., \& Astiti, D. P. (2020). Gaya Kepemimpinan Transformasional: Tingkatkan Work Engagement. Jurnal Buletin Ilmiah Psikologi, 1(3). https://doi.org/10.24014/pib.v1i3.9940.

Ardiansyah, A., \& Artadita, S. (2021). Kinerja Karyawan Melalui Keterlibatan Karyawan Sebagai Variabel Intervening ( Studi pada Divisi Produksi PT . Inoac Polytechno Indonesia Plan Tangerang ). Jurnal Manajemen, $8(5)$, 6289-6303. https://openlibrarypublications.telkomuniversity.ac.id/index.php/management/article/view/16 423.

Ariawaty, R. R. N. (2019). Pengaruh Employee Engagement Terhadap Work-Life Balance Karyawan. Jurnal Bisnis Dan Manajemen, 13(2), 97. https://doi.org/10.19184/bisma.v13i2.9864.

Chaerunissa, E., \& Pancasasti, R. (2021). Pengaruh Employee Engagement Dan Commitment Organization Terhadap Kinerja Pegawai Melalui Kepuasan Kerja Pegawai Sebagai Variabel Intervening. Jurnal Riset Bisnis Dan Manajemen Tirtayasa (JRBMT), 5(2), 126-146. https://doi.org/10.48181/jrbmt.v5i2.13080.

Chairiza, D., Zulkarnain, Z., \& Zahreni, S. (2018). Pengaruh Burnout dan Employee Engagement terhadap $\begin{array}{lllll}\text { Intensi Turnover Karyawan Hotel. } & \text { ANALITIKA, }\end{array}$ https://doi.org/10.31289/analitika.v10i2.1791.

Deny, J. E. P. M., \& Aslam, M. N. W. (2021). Pengaruh Budaya Organisasi, Kepemimpinan, Kompensasi Dan Pelatihan Terhadap Employee Engagement Pada Bpjs Kesehatan Kantor Pusat. Jurnal Ekonomi Manajemen Sistem Informasi, 2(4), 447-456. https://doi.org/10.31933/jemsi.v2i4.451. 
Erwina, E. (2020). Analisis Employee Engagement Melalui Dimensi Vigor, Dedication dan Absorption pada PT. Sumber Graha Sejahtera Di Kabupaten Luwu. JEMMA (Journal of Economic, Management and Accounting), 3(2), 173. https://doi.org/10.35914/jemma.v3i2.441.

Fitriani, A. (2019). Employee Engagement Pada Pt Pjb. Jurnal Psikologi : Media Ilmiah Psikologi, 17(01). https://doi.org/10.47007/jpsi.v17i01.8.

Khasanah, N. L. (2019). Pengaruh Kepemimpinan Transformasional Terhadap Kinerja Karyawan Dengan Employee Engagement sebagai Variabel Pemediasi Studi di BPRS Yogyakarta. EL-Ghiroh, 17(02), 123. https://doi.org/10.37092/el-ghiroh.v17i02.96.

Kriswanta, K., Mulyono, A., Iskandar, H., Haris Pratama, F., Wiji Astuti, D., \& Aulia, A. (2021). Pengaruh Kepemimpinan dan Pengembangan Karir Terhadap Niat untuk Tinggal dengan Keterikatan Kerja sebagai Intervening. MASTER: Jurnal Manajemen Strategik Kewirausahaan, 1(1), 37-46. https://doi.org/10.37366/master.v1i1.135.

Lansart, T. A., Tewal, B., \& Dotulong, L. O. . (2019). Pengaruh Kecerdasan Emosional, Dukungan Organisasi Dan Keadilan Organisasional Terhadap Kinerja Pegawai Di Biro Organisasi Sekretariat Daerah Pemerintah Provinsi Sulawesi Utara. Jurnal Emba: Jurnal Riset Ekonomi, Manajemen, Bisnis Dan Akuntansi, 7(4). https://doi.org/10.35794/emba.v7i4.26347.

Layantara, I., \& Perdhana, M. S. (2021). Analisis Pengaruh Job Characteristic, Perceived Organizational Support Dan Work Environtment Terhadap Job Satisfaction Dengan Employee Engagement Sebagai Variabel Mediasi. Industry and Higher Education, 3(1), 1689-1699. https://doi.org/10.36418/syntax-literate.v6i8.2474.

Lina, N. P. I. M. (2019). Analisis Faktor-Faktor Penentu Employee Engagement di PT. ABC Bandung. Ekuitas: Jurnal Pendidikan Ekonomi, 7(2). https://doi.org/10.23887/ekuitas.v7i2.17233.

Lisabella, M., \& Hasmawaty, H. (2021). Pengaruh Kepemimpinan Transformasional dan Kualitas Kehidupan Kerja (Quality of Work Life) terhadap Keterlibatan Pegawai (Employee Engagement) Serta Implikasinya pada Kepuasan Kerja Pegawai Authors. Jurnal Manajemen Pemasaran Dan SDM, 2(4). https://doi.org/10.47747/jnmpsdm.v2i4.380.

Manalu, A. R., Thamrin, R., Hasan, M., \& Syahputra, D. (2021). Pengaruh Work Engagement Terhadap Kinerja Pegawai BPJS Ketenagakerjaan. Journal of Economic and Management (JECMA), 1(02). https://doi.org/10.46772/jecma.v1i02.376.

Nafiudin, N. (2020). Peningkatan Kinerja Karyawan Pada Dealer Honda Auto Serang Banten Melalui Employee Engagement dan Komunikasi Internal. Jurnal Manajemen, 10(1), 61-83. https://doi.org/10.30656/jm.v10i1.2089.

Nurcahyo, T. W. (2021). Reward, Perceived Organizational And Supervisor Support ( Pos ), Work Life Balance Sebagai Faktor Kinerja Karyawan Melalui Employee Engagement. Jurnal Personalia, 28(1), 14-27. http://jos.unsoed.ac.id/index.php/performance/article/view/4075.

Nurdini, A., \& Firmansyah, Y. (2022). Apa Dampak Employee Engagement Terhadap Kinerja Pegawai Pada Koperasi Simpan Pinjam Mitra Sarana Karya Bandung. Jurnal Multidisiplin Madani, 2(1), 477-494. https://doi.org/10.54259/mudima.v2i1.413.

Nurfajar, N., Marzuqi, M. S., \& Rohmayati, N. (2018). Pengaruh Employee Engagement Dan Efikasi Diri Terhadap Kinerja Karyawan PT Nikomas Gemilang Divisi Pci S5 Serang Banten. Jurnal Pengembangan Wiraswasta, 20(1), 35. https://doi.org/10.33370/jpw.v20i1.174.

Pangestuti, D. C. (2018). Pengaruh Persepsi Dukungan Organisasi, Kepuasan Kerja Dan Komitmen Afektif Terhadap Organizational Citizenship Behavior. Jurnal Mitra Manajemen, 2(4), 366-381. https://doi.org/10.52160/ejmm.v2i4.128.

Prahara, S. A., \& Putri, O. S. R. (2020). Persepsi Lingkungan Kerja Fisik dengan Employee Engagement pada Karyawan. Psychopolytan : Jurnal Psikologi, 4(1), 11-16. https://doi.org/10.36341/psi.v4i1.1232.

Prananingrum, D. H. (2019). Filantropi Dan Pelayanan Rumah Sakit Berbasis Gerejawi Dalam Perspektif Hukum. Jurnal Ilmu Hukum, 3(1), 17-32. https://doi.org/10.24246/jrh.2018.v3.i1.p17-32.

Prativi, A. Y., \& Yulianti, P. (2020). Pengaruh Organizational Justice terhadap Employee Engagement melalui Organizational Identification. Jurnal Maksipreneur: Manajemen, Koperasi, Dan Entrepreneurship, 10(1), 128. https://doi.org/10.30588/jmp.v10i1.592.

Priambodo, E. P., Darokah, M., \& Diah Sari, R. E. Y. (2019). Peran Self Efficacy dan Iklim Organisasi dalam membentuk Employee Engagement melalui Komitmen Organisasi. Psympathic: Jurnal Ilmiah Psikologi, 6(2), 213-228. https://doi.org/10.15575/psy.v6i2.4974.

Pusriadi, T., \& Darma, D. C. (2020). Pengaruh Talent Management Dan Employee Engagement Terhadap Employee Capabilities: Studi Pada Karyawan Pt. Bintang Wahana Tata. Jurnal Riset Entrepreneurship, 3(1), 54. https://doi.org/10.30587/jre.v3i1.1317.

Rahmawati, A. (2022). Analisis Faktor-Faktor Yang Mempengaruhi Engagement Tenaga Pendidik Pada Program Studi Manajemen Pemasaran Politeknik Negeri Jakarta. Jurnal Ilmiah Ilmu Manajemen Dan 
Kewirausahaan 2(2). https://doi.org/10.46306/vls.v2i1.92.

Riansah, R., \& Sri, S. S. (2019). Pengaruh iklim kerja terhadap kinerja pegawai pada RSUD Ogan Komering Ulu Timur. Jurnal Signaling, http://ojs.stmikpringsewu.ac.id/index.php/signaling/article/view/808.

Rizki, N., Wulandari, S. Z., \& Suryani, A. I. (2021). Pengaruh Workplace Friendship Dan Workplace Well Being Terhadap Employee Performance Yang Dimediasi Oleh Employee Engagement. Jurnal Ekonomi, Bisnis Dan Akuntansi (JEBA), 23(3), 1-20. https: //doi.org/10.32424/jeba.v23i3.2858.

Sabbatho, K., Mintarti, S., \& Hidayati, T. (2021). Employee Engagement Sebagai Variabel Mediasi Antara Talent Management, Knowledge Sharing Dan Employee Capability. Jurnal Manajemen, 4(2). https://doi.org/10.24127/jm.v14i2.495.

Sirait, E. E. (2020). Pengaruh Kepemimpinan Transformasional Terhadap Employee Engagement Dengan Motivasi Sebagai Variable Intervening Studi Pada Salah Satu Perusahaan Pelayanan It. Jurnal Indonesia Sosial Sains, 1(4), 271-280. https://doi.org/10.36418/jiss.v1i4.45.

Sopyan, K. (2018). Pengaruh Budaya Organisasi, Kepuasan Kerja, dan Keterikatan Karyawan (Employee Engagement) terhadap Kinerja Karyawan. Jurnal Ilmu Manajemen Dan Bisnis, 6(2), 14. https://doi.org/10.17509/jimb.v6i2.13099.

Srimulyani, V. A. (2020). Talent Management dan Konsekuensinya terhadap Employee Engagement dan Employee Retention. INOBIS: Jurnal Inovasi Bisnis Dan Manajemen Indonesia, 3(4), 538-552. https://doi.org/10.31842/jurnalinobis.v3i4.157.

Steven, J., \& Prihatsanti, U. (2017). Hubungan Antara Resiliensi Dengan Work Engagement Pada Karyawan Bank Panin Cabang Menara Imperium Kuningan Jakarta. Empati, 6(3), 160-169. https://ejournal3.undip.ac.id/index.php/empati/article/view/19745.

Subekti, L., Setiawan, M., \& Sudjanto, S. (2018). Proses Peningkatan Keterlibatan Karyawan Melalui Gaya Kepemimpinan Dan Motivasi Kerja. Jurnal Bisnis Dan Manajemen, 5(1). https://doi.org/10.26905/jbm.v5i1.2322.

Sucahyowati, H., \& Hendrawan, A. (2020). Pengaruh Employee Engagement Terhadap Kinerja Karyawan pada PT MK Semarang. Jurnal Sains Teknologi Transportasi Maritim, 2(2), 9-15. https://doi.org/10.51578/j.sitektransmar.v2i2.21.

Suryaningrum, A. G., \& Silvianita, A. (2018). Analisis Faktor-Faktor Employee Engagement Tenaga Keperawatan dan Penunjang Medik di Rumah Sakit Muhammadiyah Bandung. Sosiohumanitas, 20(1), 124-137. https://doi.org/10.36555/sosiohumanitas.v20i1.53.

Tabun, M. A. (2021). Pengaruh Budaya Organisasi Terhadap Employee Engagement Pada Karyawan Baak Universitas XYZ Di Jakarta. Banking \& Management Review, 10(1), 1357-1368. https://doi.org/10.52250/bmr.v10i1.300.

Trisnawati, A. A., Sianto, K., Seansyah, L. A., \& Saputra, N. (2021). Holistic Work Engagement pada Tenaga Kesehatan di Kota Jakarta Barat: Pengaruh Digital Quotient, Authentic Leadership, dan Perceived Organizational Support selama Covid-19. Jurnal Akuntansi, Keuangan, Dan Manajemen, 2(4), 255278. https://doi.org/10.35912/jakman.v2i4.425.

Wahyudi, W. (2018). Kedudukan Badan Hukum Rumah Sakit Privat Dihubungkan Dengan Fungsi Sosio Ekonomi. Istinbath : Jurnal Hukum, 15(2), 231. https://doi.org/10.32332/istinbath.v15i2.1209.

Yusuf, R. M., Taroreh, R. N., \& Lumintang, G. G. (2019). Pengaruh Employee Engagement, Beban Kerja Dan Kepuasan Kerja Terhadap Kinerja Karyawan Pada Cv. Indospice Di Manado. Jurnal Emba: Jurnal Riset Ekonomi, Manajemen, Bisnis Dan Akuntansi, $7(4)$. https://doi.org/10.35794/emba.v7i4.25429. 